\title{
岩木盆地に於けるりんご生產分布の發展過程に基く
}

\section{Area Differentiation}

——量的変化の法則性にのいてー-

長谷川 典夫

I. 序論 份木盆地は毒森県西部に位する広い 冲箖平野で西南部を東流する岩木川は弘前附近て

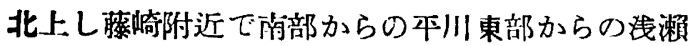
石川を合し,こ〉て廣大な自然堤防を形成しつ〉 遠く十三潟に流入する。盆地の東部は奥旸山脉及 び那須火山脉が速り西部は北は菂風山脉の砂 丘が発達し南に岩木火山が広い裾野を作つて おり盆地周囲は一般に洪稓段丘が発卖してい る。りんご園はてれらの地形に応じて主とし て自然堤防 $こ$ 中南部の段丘面等の緩倾斜地及 び岩木山の裾野に広汎に分有している。

而して岩木盆地注文化的消費的中心から遠 隔の地に在り, 主として所謂経済的距離性及 び出荷期に帰せらるへさ市場との価額関係 ${ }^{(1)}$ は, 他のりんご栽培地に比してその位置を不 良ならしめているにも拘らす, 栽培開始以来 僅々 80 年の間に日本全虐額の $67 \%$, 6760万 貫, 青森県の $88 \%$ を花出する(2) 亿至つてお り,か〉る急速なるりんご栽培の拡大はその 発展過程の地域的配罳を調心るるに恰好な素 材を提供して吳れる。

先に G. T. Trewartha ${ }^{(3)}$ は巧妙な筆絰で岩 木盈地りんご栽培の景観抄寫を試みその特色 を遺憾なく明示される。灭石川武彥氏(4)は立。 地論的立場から，波多江久吉氏 ${ }^{(5)}$ 沈経済発達 史的立場からそれぞれ当地力のりんご裁培を 研究されているが，それらの吟味は直接筆者 の志す所ではない。

曾て Alfred Rühl ${ }^{(6)}$ が農業の発達過程の 経済史的展望の必要を說きつ〉時代的に相異 せる分布より, 中心域の移動及びその普遍化
に就いて特に交通機関との関聯の意義を力說した が，それは研笑方法に大きな示惨を与へて吳れ た。しかし問題はかつる核心の移動或は普遍化が 行われると否とに拘らす，その截培の量的経済的 発展が如们なる過程を経て現在の Area differentiation を生し或はSpecializeされて行つたかを言

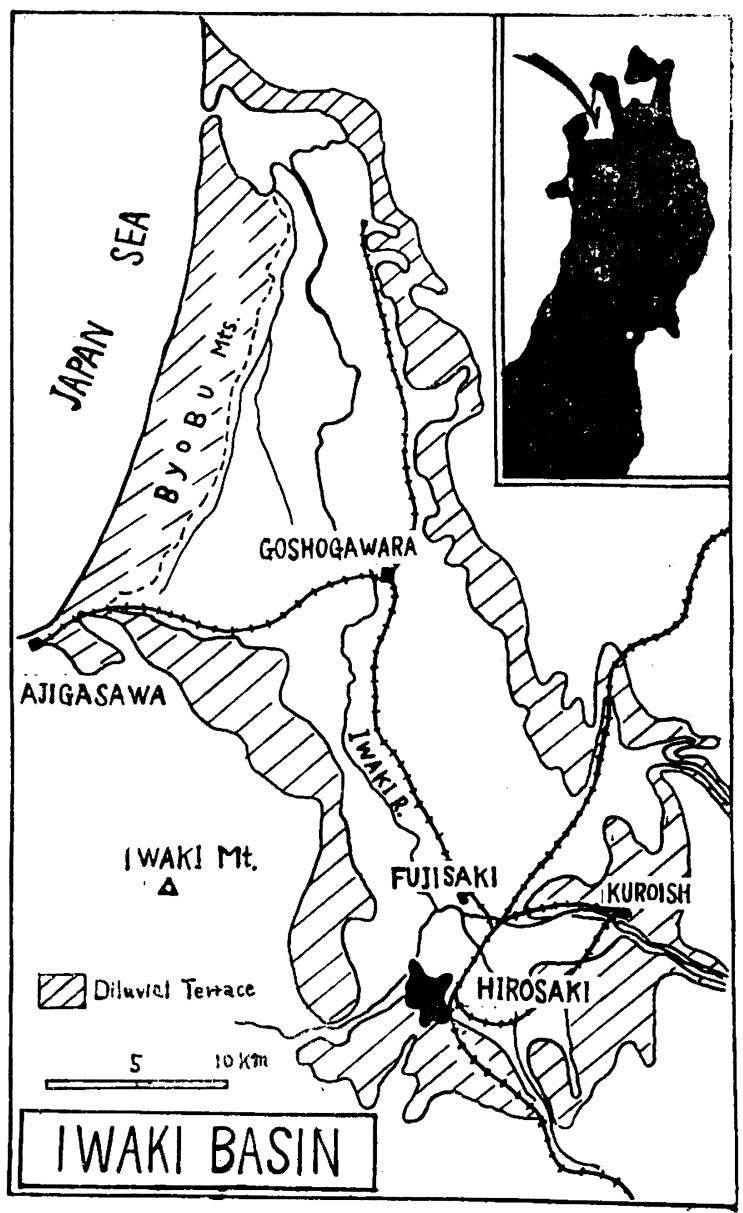

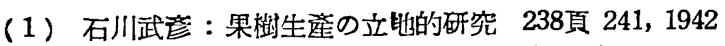

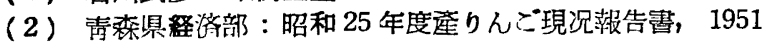

(3) G.T.Trewartha : The Iwaki Basin, Reconnaissance Field Study of a Specialized Apple

District in Northern Honshu, Japan. Ann. Ass. Am. Geogrs., Vol.20, 1930, pp. 196-223.

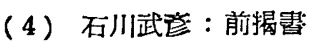

（5）波多汇久吉 : 青森県りんご経沮発澾果

(6) Alfred Rühl : Das Standortsproblem in der Landwirtschaftsgeographie.

Verōffentlichungen des Instituts für Meereskunde an Universität Berlin,

B. Historisch-Volkswirtschaftliche Reiche, Heft 6, 1929. 
万事に関して，時間的変化拈程の地场的相異几基 くPatternを明示する事にある。従来地理的諧栐 相の時間的変化を取找ふ場合, 例へば F. Kniffen の Agricultural Fair や P.E. James の Brazil 農 咩の論文の)如く時代的分布図の比较のみを以てす る分析が最も一般的であつたしかし之と異つ $\tau$, 例へば, T.W.Freeman ${ }^{(7)}$ は Western Ireland の Congested Districts を論するに当り，時代的な Population Density の分死亡共にそれらの変化自 体を図示してその意義を諭述し，N. Hilton ${ }^{(8)}$ は Chronological に農業の発達及びその要因を究め んそして, 各時代の分布図を作成の後洔閒的過 程帛通じて得た性格によつ $\tau$ Changes in the Margin of Cultivaionなる地図を作り地域 区分を行つている。即ち分布の時 間的変化から新たにその変化過 程の性格として Region を設定 図示しそれを說明する方法で， 特に人口の研究に於ては比较的 多く使用される様である。E.C. Willatts,MarionG.C.Newson, ${ }^{(9)}$ Arthur Geddes ${ }^{(10)}$ の論述の如き がそれでする。しかし農紫の單 一生座に於ける分布の発展か;急 激な变化を持たね場合に，それ を時間的に定量化し且つ変化過 程を問題とする事は甚だ困難で あり，その限り A. Rühlが指標 に主として果樹類その他商業的 色彩の强い作物を撰ん だのは穻当である。こ 〉に筆者は岩木盈地に 於けるりんご栽培を例
てより，生产発澾の時間的変化の Process 飞基 くArea Differentiation 追求しその法则性を見 部しょ5とする。

この㥞な農業生座の発展に䦎してはT.H.Engelbrechtの相対分坊に付いて既にT.Brinkmann ${ }^{(11)}$ も指摘した如く，量的側面に対もる質的側面，即 ち経営集約度及び経営ぢ式の地域的異同の問題を 考虑する事は是非必要ですり, 徒つて, 量的㹡大 の過程の相遱に基く Area Differentiation に対し て資的侧面の発垡及びその現䧳分析に付ては次の 機会に諭ぜられねばならない。

II. 分布擴大の史的槪略 ${ }^{(*)}$ 明治初期飞導入さ

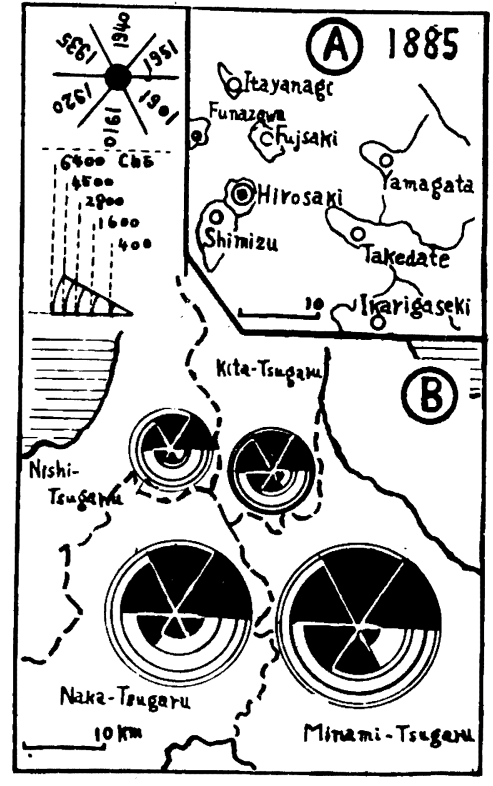
れたりんごが從来の辰業の「停 㵲性を一挙に破壤する强靶さる 持たなかつた」(12)のは言ふ迄も ないがそそれは旧藩士族・富裕

Fig.1 A. 明治18年主要栽培地

B. 郡別累年りんご園面稙

C. 青森県,りんご生量及び 面皘の累年变化

(縱軸的は千町步, 百万箱単位)

(B) (n) 
農家・地主階級に依つて開始されに裁培が以後も 必然的に彼等て指導者の地位を保持せしめる絬果 を生し，篇にその截培は地域的に一限定されし かも散在的なものに過ぎかつた。即ち弘前・清 水周辺, 次いで船沢・藤崎・板柳・竹館・䃌ケ関・

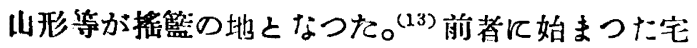
地襄の栽培は明治 18 年以後, 後者つ時代に入るに 及んて野外の栽培を開始した。之等の土地の以前 の利用は主として和地・河岸地つ荣重・馬鈴擎・ 雜款・煙草畑であり，その他荒地探草地であつた。 (14) (*) かつる播篦地がその後の発展を通して常に 大きな比重を上めて柬た事はその端䌋が自然発生 的ではあるにしろ大きな意義を持つものである。 以後, 明治 23 年明治 $27 \cdot 28$ 年の経済的好况几低る 拡大, その原始的粗放的栽培の弱点に由来する明 治 31 年以後の挤出害の侵害, 及びそれを契機とす る集約経營への脫皮(明治38年略完了)，明治40年の 民伤原野の解放を契機とする自作農の生計補完的 小商品生產的栽培の拡大等り経過し，一方に於て は集约的経営として地主の手作りからりんご園分 割による農民的経営が伸鿟し栽培面积は明治38年 〜大正 7 年に的 5 倍 (1508町一8029町) の增加を示 した。⑮) 播籃の地を中心に盆地中部南部の倾斜地 一帶及び自然埙防に急激な增加在示したのはまさ 飞此の時期であつた：しかるに明治 43 年以後大 正 7 年までの間は，栽培地の拡大は收量の篁大を 伴わす，生恐慌を機として科学導入対策が權ぜ られ(16), 大正 9 年栽培は概ね安定し, 大正 9 年 大正 14 年には整借保全て集中され增植は比较的 少かつた。かくて昭和 8 年頃より再び急激な增植 て転じにのであるか，時恰かも昭和農村恐慌に上 る不况及び昭和 6 年 9 年 10 年亡相次ぐ冷害凶作 により倩弱の爲に所有地の売却及び小作八の轉落
著しく，一污りんご園経営が水田單作に比し凶作 による啙家経済破壞に対する抵抗力か强かつた事 から, 水田單作地方の補完的小商品生成之して, 小䙺模な小舆民的経営の增大・零練経営者の続出 は，りんご裁埰つ塤加普及る促進せしいたのです つた，更に昭利12年日菲事変て於ける㖘産物価格

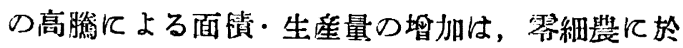
ける労仂つ强化及び大規模経営に於行る㕍俏労仂

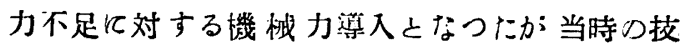
術段階に於ける労仂集的的経営走資本投下儿上る 生座手段の上向几依つて近代的企㮍にまで到達す る事は困踓であり，か〉る意味で裁咥つ拡大にも 或る程度つ㸡限があつた事仗事実である。太平洋

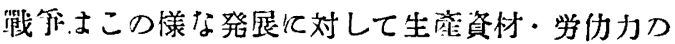
面から压旦し，統非経済つ强厅と相俟つて忙び面 秥つ渐減を强要したか;，戰後インフレーションの

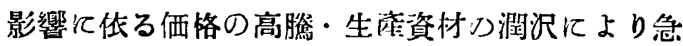
速に復興し, 戰徯つ面摃的拡大は公程著しくない が,この過程に於て経営合理化への準借は着々整 借されて將来の方式に多くの示哭を投げている事 は見洮が得ない，

III- 分布搪大の波動減衰運動 経済史的展望 によればりんご栽培発達の過程に於りる拡大傾向 は栕々に変化し, 大正 7 年より昭和 3 年艺は狢停 溜し, 以後昭和 16 年迄は堵加つ一途它辿り, 戰時 及び戰後て急激な減少及び增加を見ている。全般 的には增加倾向を示す。しかしての梯な变化があ つたに\&拘らす，変化過程の相異に関して地域的 配列が見られる事は以下逃べる通りである。

ここに現在つ樹令からりんこ園形成の時期を推

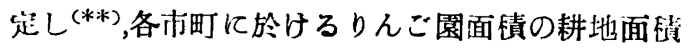
に対する比率及びその各 5 ヶ年の契加を計算し, $(* * *)(* * * *)$ 前者をりんご園の「分布指數」, 後者

* 長谷川興夫 : 岩木盆地のりんご裁堮—1952年度東北大学卒業論文

** 岩木轻地全般に沉る年次別のりんで園面皘の資料がなかつた事, 大正 9 年以後为 2 次大戦を除いては枯 死，败植は比較的少かつた事から，樹合面棈を以て代用した。

*** 資料の関保上大正 9 年か 5 昭和 6 年までは 10 年間をこつた。

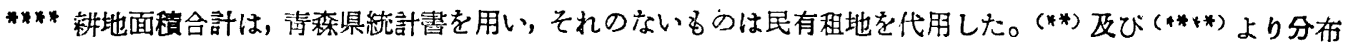

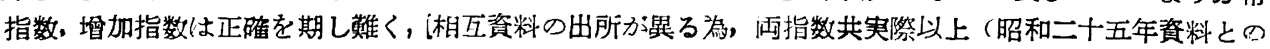
比较に於いて)に大きく表現されている場合もあるが，相互の場所的比較には支障ないと思はれる。

（13）対馬東紅：りんごを語る，8-9頁 昭和 9 年

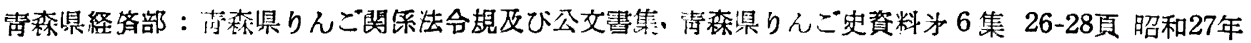

(14) 対馬東紅：前掲霄, 8頁

(15) 海森県りんで課調查

(16) 青森県経络部：放揭資料为 6 菜

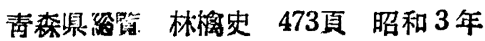




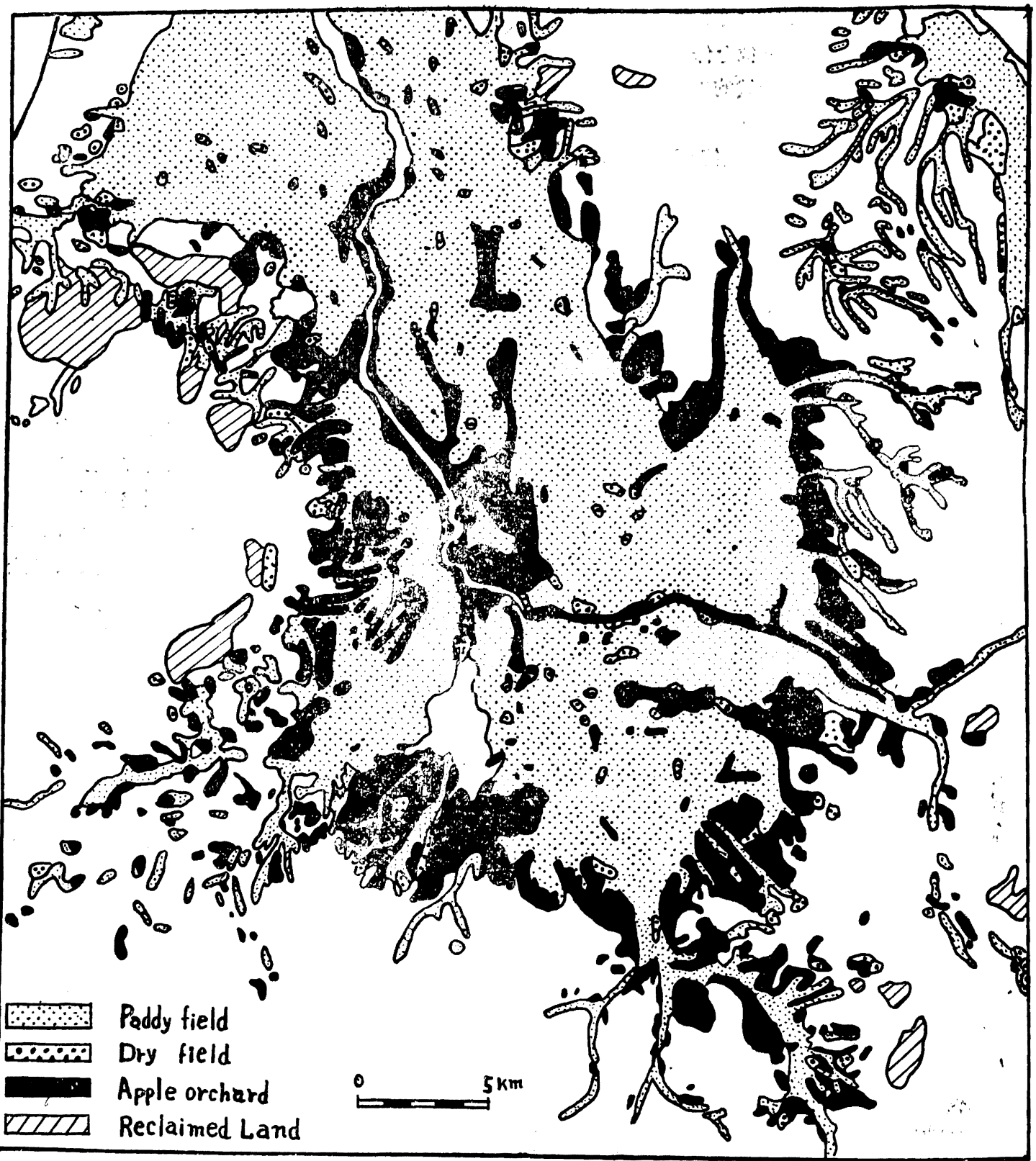

Eig. 2 岩木盆地主要部の土地利用

は之を「增加指数」と仮称する。

今大正 9 年, 昭和 6 年, 11 年, 16 年, 21 年, 26 年 各分布指數を図示すれば (Fig. 3)， んづれも一般に 分布指数は早則に截培され発展した地方程大き く，分们の発展か门搖篮地を中心にその周四に㹡大 して行く過程が示され，その過程に於て自然奖 防及ひ綬倾斜地が急速にりんご嵲化し，盆地和 消部が水田地带として殘されている事ね看取す る。更に之等各賭加指数の Mapping は (省略) 增

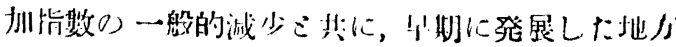

は增加指数がー一般に大きい事を示す。即ち大正 9 年の分布に於て盆地南東部は分枋指數兓に 40 に 蓬し, Natural levee, 岩木山麓・弘前附近は 15 几 達していた。大正 9 年〜昭和 6 年に盆地中南部の 東西両側傾斜地は低然增大し続け, 水田地帶及ひ 中部以北は殆ど停帮的である。昭和 6 年〜11年に 系る之增加指數は次第几減少し, 特に東南部傾斜 地では殆ど upper limit に達した如く, 弘前附近 及び盆地中部傾斜地に此較的大きな発展を示す。 昭和 11 年〜16 年には南西部倾斜地中比较的奥地 

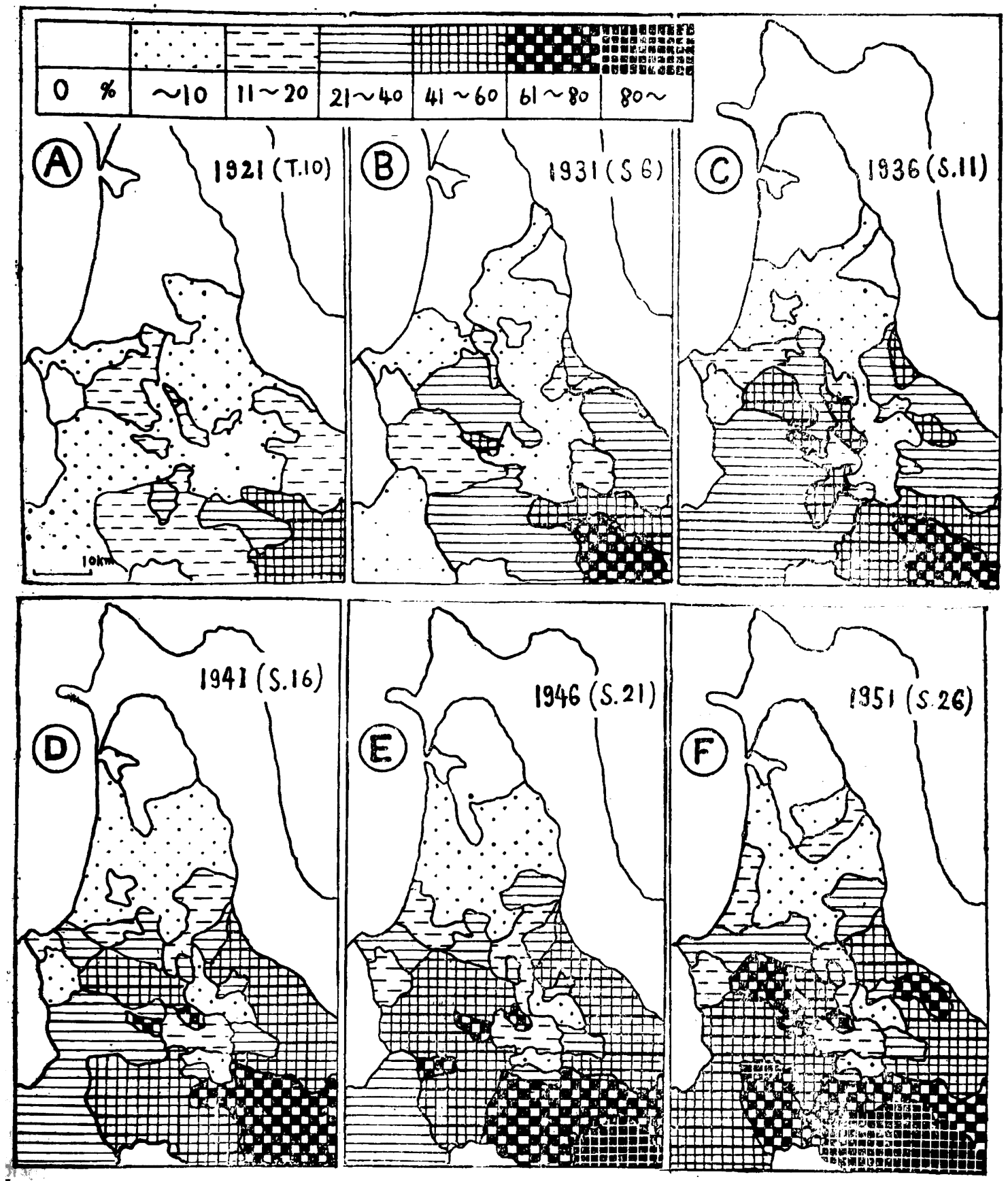

Fig. 3 分 布 指 数

が交通機関の整備と共に特に增加している。昭和 16年～21年江既江戰時体制に於ける諸困難加增 加は極めて少くなつているが,盆地北部にや〉注 月すべき增加を見せている。戰後㣖一般には南部 の停滞性に対して北部の留加が少い作ら看過出來 ぬ現象である。

邓各町村の埖加指數の Peak を取りその時期に
関してクラブを示せば (Fig. 4·B) 增加指數の Peak て早く到達した地方程 Peak の洒は大きい。

次に燴加指數か; Peak に達した時期を基準に図 を描けば(Fig. 4.A)かつる時間的変化の過程の相異 に基く Pattern は初期的裁培地より次第に周囲に 伸長する距離的配列を示す。

以上を要約して增加指數の変化をグラフに六し 

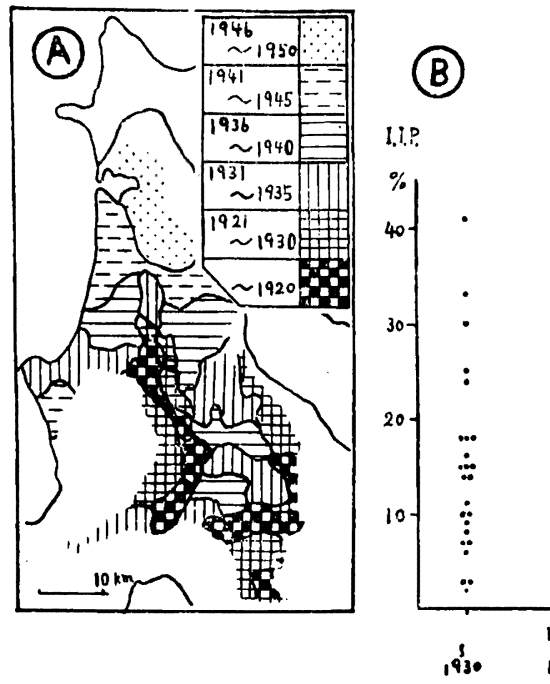

た結果 (Fig 4.C), 增加指數の Peak の傅播, 即ち Peak に到達した時期による分布の Patternは,

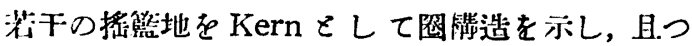
Peakの大きさは Kernに近い程大きいとい5軎実, 撸言すれば㙁加指數及びその Peak 注 Kern 地域 からの距離と時間との函數とて移動変化するとい 5事が碓認される。からる発展変化を「生度の波 動減䒾運動」之名付ける。

IV. 增加及び減少傾向にある品種 2 例 分布の 㹡大過程のか」る運動を考へる際我々はそれに関

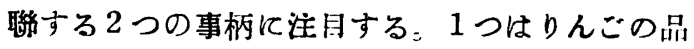
程に就ても分仍及びその発展に地域的相異が見ら れる事であり，他つ1つはか」る分布の㹡大が時 間的に不均衡であつた雼若干の地域に深刻な老樹 崩解の問題を提起している事である。共に立こし て, 改植に多額の資本を要する篇, 栽培は新植時の 経営に右右される結果である。品蝩の分布の問題 亿䦎しては特に㙁減の傾问著しい「デリシャス系」 及び「紅絞」についてのみ之を論述し, 後者は別稿 に発表の予定である。

りんご品毢て関して單に分布の地域的相異が認 められる以外に, 需要の堆減·品種固有の生産量・

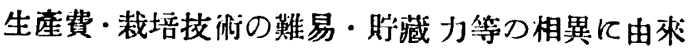

(c)

Fig. 4

A. 筧加指数加

Peak K䔔し た時期による 区分

B. Peakの大き さとその時期 I.I.P. $=$ 增加指 数の Peak

C 增加指数の 变化 II. = 壖加指数

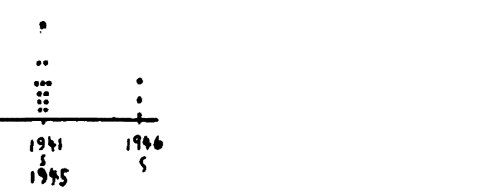

Dellcrous

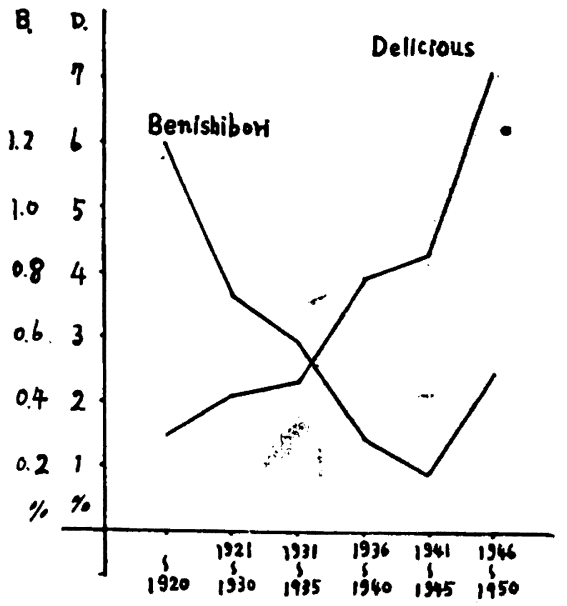

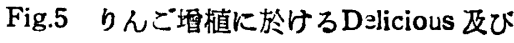
紅絞の割合

する特定品種の賭加傾向及び減少傾向が㐿在し， この傾向は経營農家の性格に反.胦される之同時に 地域的にも異つている。明治 23 年に 61 種に及ん だ(17) りんご品種は次第几淘汰されて主要品種た る国光・紅玉へつ集中傾向か著しん(18)。此処に は新しい品種として国民の搘好と合致し生食用よ して極めて传良で方場価格が高いが，不良土堙に 対しての適応力が小さく收獲前落果が多いとい 次尔点をも侍する ${ }^{(19)}$ デリシャス系と，種くの面て

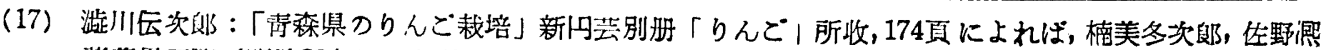
潜茶果要筧（岄治23年）に記载されてるる

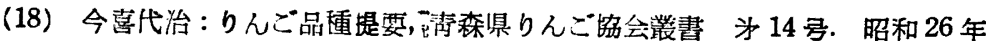

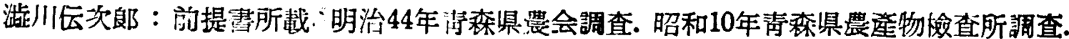

（19）今喜代治：りんご品種概要, 上㨡 昭和 25 年青森県りんこ課調查：

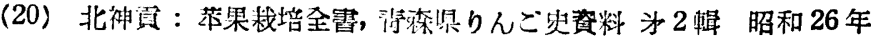
石川武：前揭電. 208頁によれば 15 年を要する。 


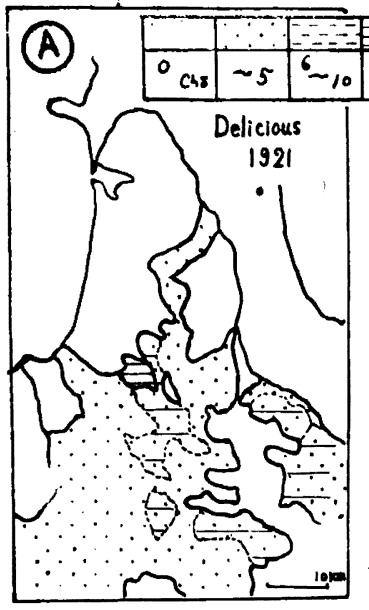

Fig. 6-A

Fig.6 Delicious面皘
(B)

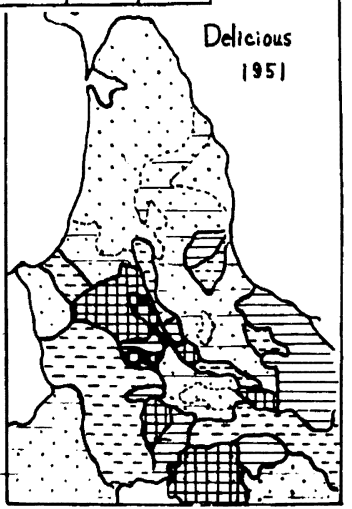

Fig 6-B

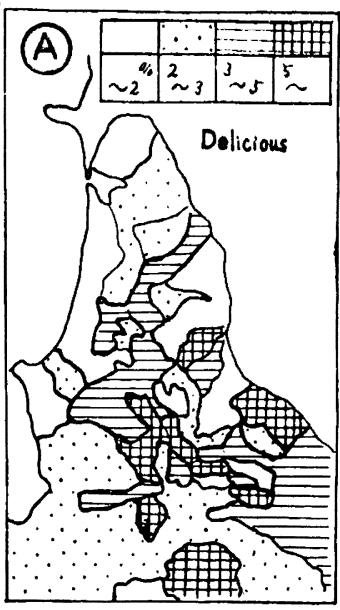

Fig. 7-A

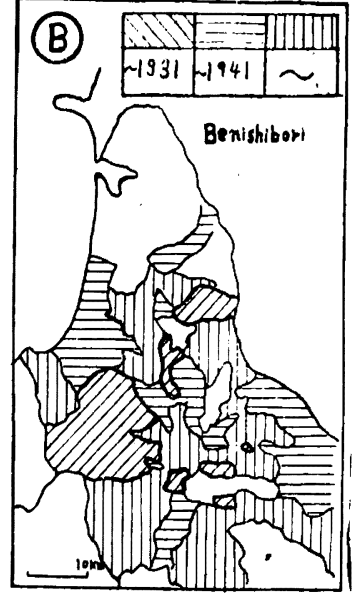

Fig. 7-B

Fig.7 A. 1921〜1951 のりんご增加に対するDelicious 堽加の，割合 B. 紅絞の新植の行われなくなつた将期

淘汰され減少の一途を辿りごく一部の需努に応へ つ〉ある紅絞とを取上げ，その增加新植か；如何に 地域的に相異するかを䠐察する。先に储れた如く， 戰前に於てりんごの壮植開始より收支の Balance が取れるに到る汽には概ね 10 年を要し, ${ }^{(30)}$ 戰後 の Inflation は此の期間を一時的に短縮したか; 佾 且つ此の样な長期鬥の支出超過飞耐へるには相当 額の資本が必要であり，栽植後の大規模改植は困 難で品種の增減は概ねその品重の新植時に決定さ れる。今青森県に於けるデリシャス系. 紅絞の樹令 による栽植時期每の面積は下表の如く，各期間に 栽植されたりんご園面積全部に対する,デリシャ ス系及び紅絞の 割合の変化を図示すれば(Fig.5), 両品種の比重の增減相反し、た傾向が認められ特に 昭和 6 年 20年に於て著しい。

大正 9 年及で昭和 26 年のデリシャス系の面積, 及び大正 9 年〜昭和 26 年行新たに栽 植されたり んご園全面皘に対する同デリシャス系面樍の割合 は (Fig 6A.B.) (Fig. 7.A)の通りである。即ち大正 9 年には岩木川の自然堤防附近·岩木山周辺·弘前附 近几栽培され, 盆地東部傾斜地飞る若于裁培され ていたか，昭和 26 年には之等の地域は著しく比重 を增加し，他は若干の㙁加を見る。こっイデリシ
ヤス矛:の增加傾向は距離的配列を示しりんご全 体の拉大倾向と略 Correspond している。そこて 楛干の例をとり各期のりんご增加分に対するデリ シヤス系塯加の制合を示すと（Fig.8,A)，それが他品 種に比し有利性を保持する限り，早猢に発展した 地方は增加傾向が大きく，又若し経済的有利性が 失はれる傾向を生するなら，地域的汇大きさ之時 期との異なつたPeakが生するであろらと考へら れる。

次に変退途上にある 紅絞に就て見ると，既に新 植の行われなくなつている地方が多數あり，新植 の行われなくなつた時期 (Fig.7,B) 及び若干例の 各時期によるりんご增加分に対する紅絞增加分の 割合 (Fig.8,B)を調へる事に依りりんご截培の早 くより行われた発展の著しかつた地方程一般に早 期飞且つ急激飞減少消失している事か;知られる。

V. 波動減衰運動の意義 上述の波動減衰運動 を丞約すれば次の如くでする。（1）りんこ園分 们の時間的各断面に於て距離的要素のみを考虙す ると，相対 分布量 (分布指数) は中心加ら心距雖 之共に次營に減少する。他面よりすれば時間的拡 大過程は場所的に異なり中心に近い程早く摭大 ししか子分布指數值も大きい。(2)增加指數の

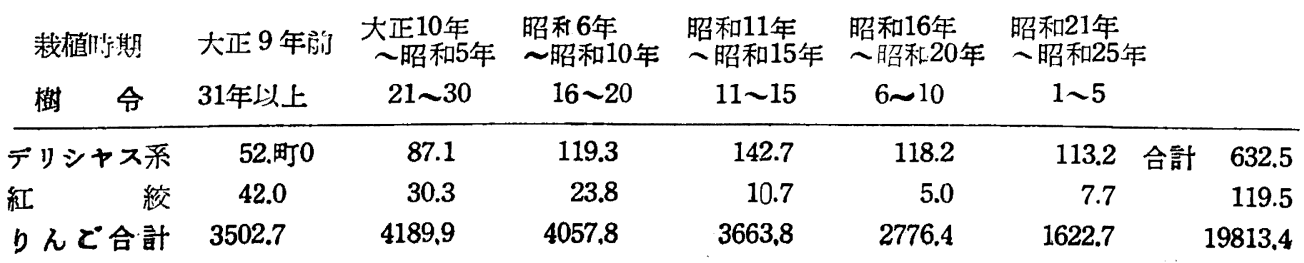


Peak の存する时期は各地域に より異なり中心に近い程早期 に Peak に到䞗する。（3）篔加 指数の Peak の值は早·期に達し たもの程大である。（4）從つ 七嫶加指數の变化は時間之距離 の画數として表はされ，中心に 近程 Peak はをく早く到来 する。ここに分布の揢大は波動 減衰運動を行小。（5）任意の 時間に於ける生產諸関係の変化 自然的意味の変化による適地広 狹の変化, 需要の変化, 交通機関 の変化等を生した場今，それ Accident と呼ぶなら, Accident 以後垻加指數の傾向は急激に变 化し，二次的Peak 形成し，或 は加速的に指數は減少する。又 從来の中心を中心之した距離 的配置之同一の場合及ひ别の秩 序に配列される場合もある之考 へられる。この Accident の局 部的展開が一般法則の例外とし Fig. 82 品貍の增加のりんご增加に奶する割合 て認められる所のものである(*)。
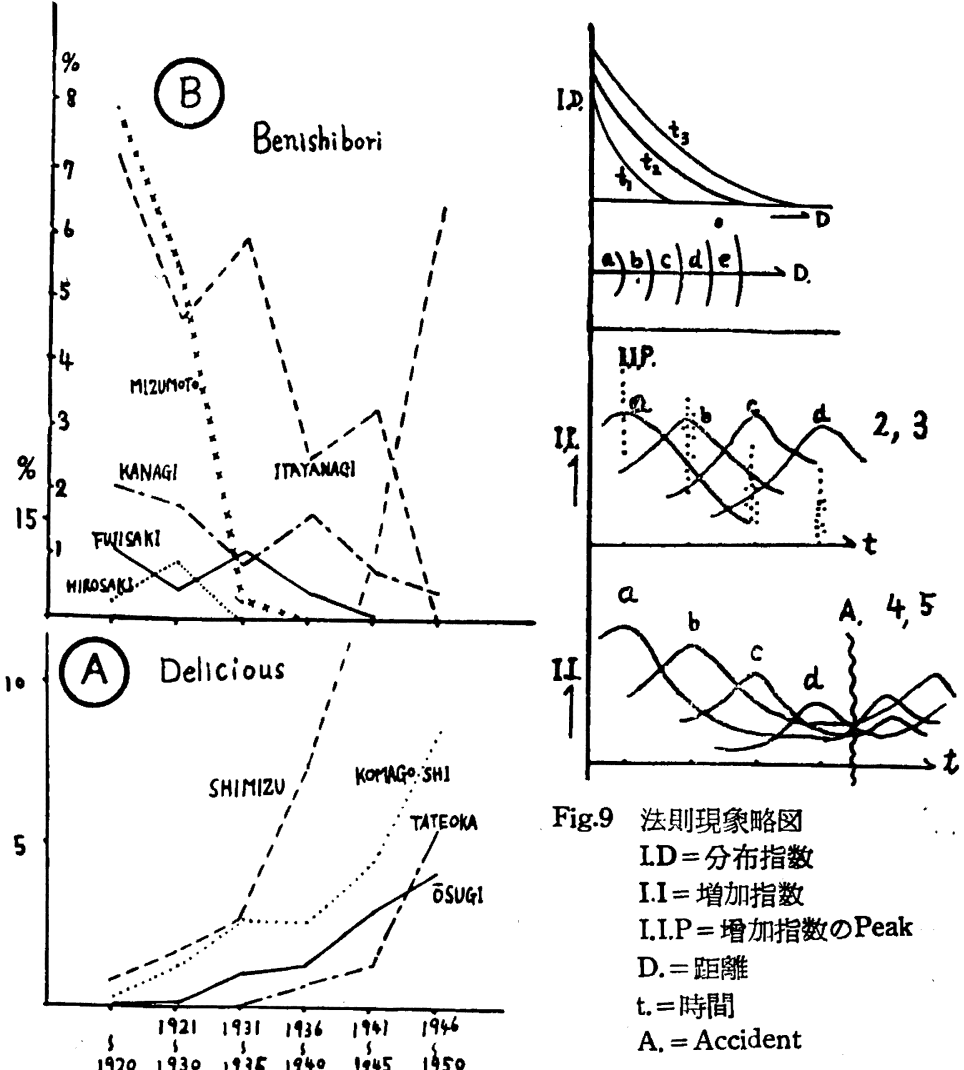

Fig.9 法則現皱略図

I. $\mathrm{D}=$ 分布指数

$I . I=$ 增加指数

I.I.P =增加指数のPeak

D. =距離

$\mathrm{t} .=$ 時間

A. $=$ Accident
（6）以上は相対分布よりせるりんごの量的擴大面

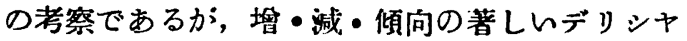
ス系・紅絞の如を少量品種の分布に於ても质〉上 訅と同じ变化系列を示し配置住概ね Correspond

\section{している。}

從来時間的変化過程の地域的相異に基く Patternに関しては主として人口の面より取トげられ， しかも此較的簡單な操作によるものに過をなかつ た。篚者沬 A.Rühl の方法を発展せしめ, 人口の 面より行はれていた方法を採用し，相対分布の変 化を時間的段階の集皘・連続として取报ふ事に 依つて, 分布の時間的変化過程に基く地域的相異 を波動減衰運動亡して導き出す事が出来た。しか
しか」る 発展要因乃至法則性の合理的解釋は，り んこ栽培の貭的分析る詳細に行つた後明かにされ 得る之考へられる。勿論所謂商業的農業の一典型 として岩木盈地のりんで栽培には農業て於ける資 本主義の諸特徵か：比校的明瞭な形で示されるへ きであり，從つて之等を指標とした稹的分析が特 に必要で，如何なる農民階級によつて如何なる場 所で探用されて来たか，祳民意識け低位が如何に 反映されて 来たか等之共に，發展の遲速に依つて 導入或は転化された裁培資本が如何に発展しつ」 あるかの問題も强く浮彫されねばならない。此処 では統計面に表われた數量の発展型を波動減表運 動として示すに止めておく。 